\title{
PHARMACOLOGICAL STUDIES OF PANAX GINSENG ROOT: ESTIMATION OF PHARMACOLOGICAL ACTIONS OF PANAX GINSENG ROOT
}

\author{
Keijiro TAKAGI, Hiroshi SAITO and Hiroyuki NABATA \\ Department of Chemical Pharmacology. Faculty of Pharmaceutical Sciences, \\ University of Tokyo, Bunkyo-ku, Tokyo, Japan \\ Received for publication October 11, 1971
}

Ginseng root has been utilized for thousands of years in China, Korea and Japan as an important drug in Chinese medicine. Chemical researches on Ginseng root have been reported by a number of investigators (1-8), especially Shibata and his co-workers have investigated the chemical structure of Japan-cultivate-Panax gieseng saponins and sapogenins (9-16).

Several papers concerning the extracts of Ginseng root have been reported in the pharmacological fields (17-21). Petkov (22 24) reported the stimulant effects of Ginseng root on the central nervous system, the respiration and the adrenal cortex. It was reported that Ginseng rool stimulates gastric and intestinal motility (25), corrects nutritional disorders (26) and depresses mean arterial blood pressure (27). Wood et al. (28) investigated the effect of Ginseng root on cardiovascular system in the dog.

It is very difficult and costly to study systematically detailed pharmacological effects of oriental plants. In our laboratory, a systematic analysis of pharmacological properties of a chemical compound have been studied (29). This analytical method was appliedto the study of Ginseng root saponins.

\section{MATERIALS AND METHODS}

Pharmacological properties of extracts of Ginseng root were estimated by blind screening which consisted of three tests: 1) neuropharmacological observation in mice, 2) tests on the respiratory and the cardiovascular system in the rat and 3) tests on the guinea pig isolated ilcum.

\section{1) Netropharmacological observation in mice}

This method is based upon the work of Irwin (30) and has been modified by many investigators. The test substance is administered intraperitoneally to mice. A useful logarithmic series for dosing is : ..... 1,2,5,10,20,50,.... $\mathrm{mg} / \mathrm{kg}$ (from the dose which induce symptoms similar to those of a control animal to approx : $L D_{50}$ ). Observations are made for $2 \mathrm{hr}$ and then after $24 \mathrm{hr}$. Results are recorded in tabular form, Tables 1, 2 and 3. Details can be found in the report by Takagi and Saito (29). 
2) Tests on the respiratory and the cardiovascular system in the rat

After the rat is antesthelized intraperitoneally with urethan-chloralose, both the arterial blood pressure and the heart rate are recorded from femoral artery via a pressure transducer (Nihon Kohden, MPU-0.5) and polygraph (Nihon Kohden, PM-150). Boll carotid arteries are exposed, then, the vagus nerve. A bilatcral vagotomy is performed and an electrode is attached to the peripheral vagus stump. A femoral vein is prepared for intravenous injection of test substance. Electrical stimulation ( $5 \mathrm{~V}, 2 \mathrm{sec}, 30 \mathrm{c.p} . \mathrm{m}$.) of the vagal stump and occlusion of both carotid arteries for $20 \mathrm{sec}$, are done. The responses on respiratory system are recorded using a pressure transducer (Nihon Kohden, LPU-0.1) and polygraph (Nihon Kohden, RM-150), through a cuffed and Y-shaped endotracheal lube.

Effects of acetylcholine, epinephrine, histanine, atropine, diphenhydramine, propranolol and phentolamine on the respiratory and the cardiovascular response to Ginseng root are also studied. Doses of these substances are injected: acetylcholine $2 / \mathrm{gg} / \mathrm{kg}$, epinephrine $5 \mu \mathrm{g} / \mathrm{kg}$, histamine $5 \mu \mathrm{gg} / \mathrm{kg}$, atropine $2 \mathrm{mg} / \mathrm{kg}$, diphenhydramine $3 \mathrm{mg} / \mathrm{kg}$, propranolol $250 \mathrm{fg} / \mathrm{kg}$ and phentolamine $0.5 \mathrm{mg} / \mathrm{kg}$, respectively.

3) Tests on the guinea pis isolated ileun

Male guinea pigs are sacrificed by a blow on the head. The abdomen is opened using scissors and a $2.5-3.0 \mathrm{~cm}$ length of intestine, cut off about $20 \mathrm{~cm}$ from the pylorus, is suspended in Tyrode's solution bubbled with air in a $10 \mathrm{ml}$ organ bath kept at $32 \mathrm{C}$. The responses of the ileum to test substances are recorded isotonically on a smoked paper. The antagonism to the contractions induced by acetylcholine, histamine, nicotine and serotonin are studied. Acetylcholine and histamine are added cumulatively, and nicotine and serotonin are added at the concentration of $3 \times 10^{-6} \mathrm{~g} / \mathrm{ml}$ to the organ bath. The results given are the averages of 8 experiments ( 4 animals).

\section{4) Animals}

Male mice (ddy-strain), weighing 18 20 g., male rats (Wistar-strain), weighing $300-400 \mathrm{~g}$, and male guinea pigs, weighing 250-350 g, were used.

5) Preparation of extracts from Ginseng root

Ginseng roots were treated by Shibata et al. (12) as shown in Fig. 1. GNS: This fraction is a mixture of saponins which are composed of neutral saponins, Ginsenoside $\mathrm{Rb}$ and Re mainly. G. No. 4: This fraction contains Ginsenoside Rg. 1, Rg. 2 and Rg. 3, but Rg. 1 is the main component. G. No. 5: This fraction is lypophilic fraction. GNS and G. No. 4 were dissolved in physiological saline and G. No. 5 was

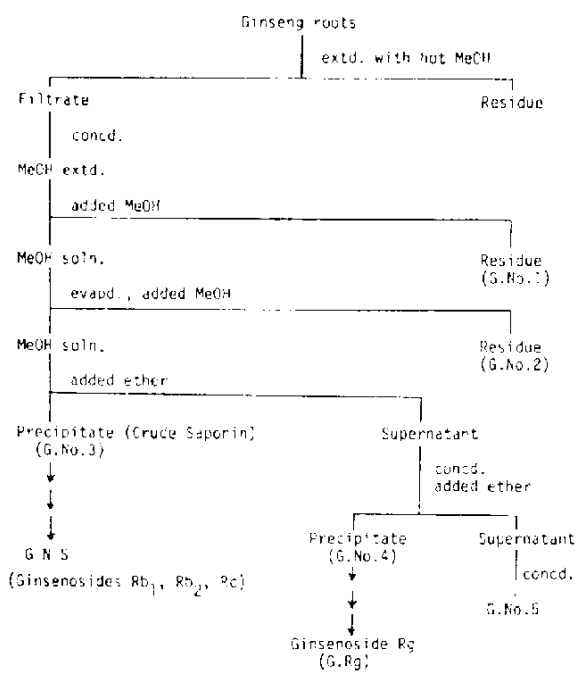

Fic. 1. Separation of the Ginseng roots. 
suspended in physiological saline with a drop of Tween 80 .

\section{RESULTS}

\section{Neuropharmacological observation in mice}

\section{1) GNS}

Table 1 shows the pattern of changes in general behavior induced by GNS in mice. From the number of survivors in each group, an approx. intraperitoncal LD $_{50}$ of GNS in mice was calculated to be about $500 \mathrm{mg} / \mathrm{kg}$.

In a dose of $500 \mathrm{mg} / \mathrm{kg}$, GNS produced a decreasc of alertness, grooming, motor activity and body temperature, and an increase of passivity approx. 30 min after the administration. Relaxation of the skeletal muscles and an extended posture with abdomen touching floor were also observed. Disappearance of pinna reflex and righting reflex, ptosis and abnormal gait were also observed at the same time. These changes of behavior continued for several hr with the mice dying $24 \mathrm{hr}$ aftcr administration.

In doses of $20-200 \mathrm{mg} / \mathrm{kg}$ given intraperitoneally to mice, the drug produced the follow-

TABLE 1. Effect of GNS on neuropharnacological observations in mice. The score card for GNS shows results obtained in neuropharmacological screening procedure of Takagi et al. (29).

Central and autonomic nervous system activity and acute toxicity screen

$$
\text { GNS }
$$

Strain : ddy, Sex : $\hat{\jmath}$, weight : 18-20g.

Vehicle : Saline, pH : 7, Route : i.p.,

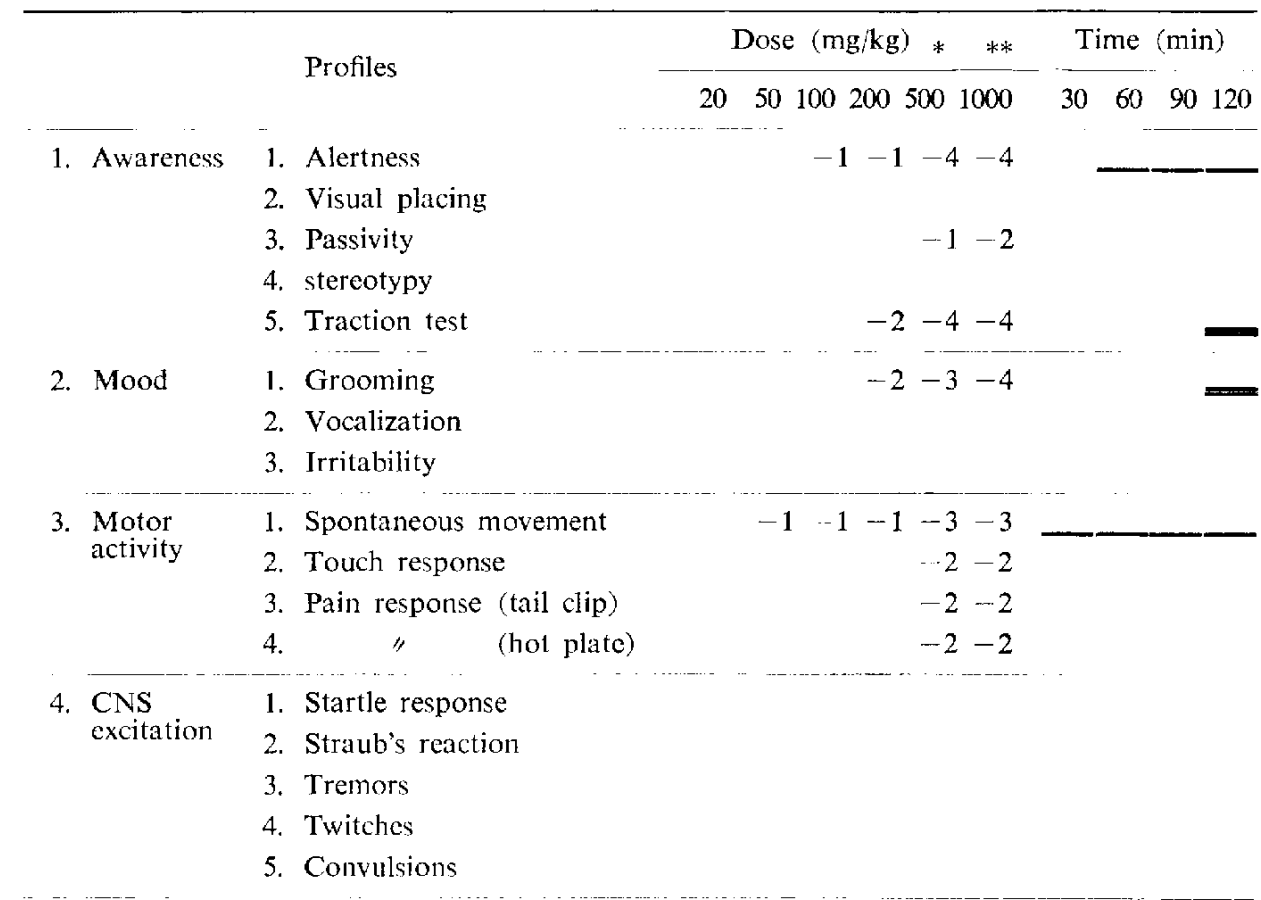

5. Body posture

$$
\begin{array}{llll}
-1 & -1 & -2 & -2
\end{array}
$$




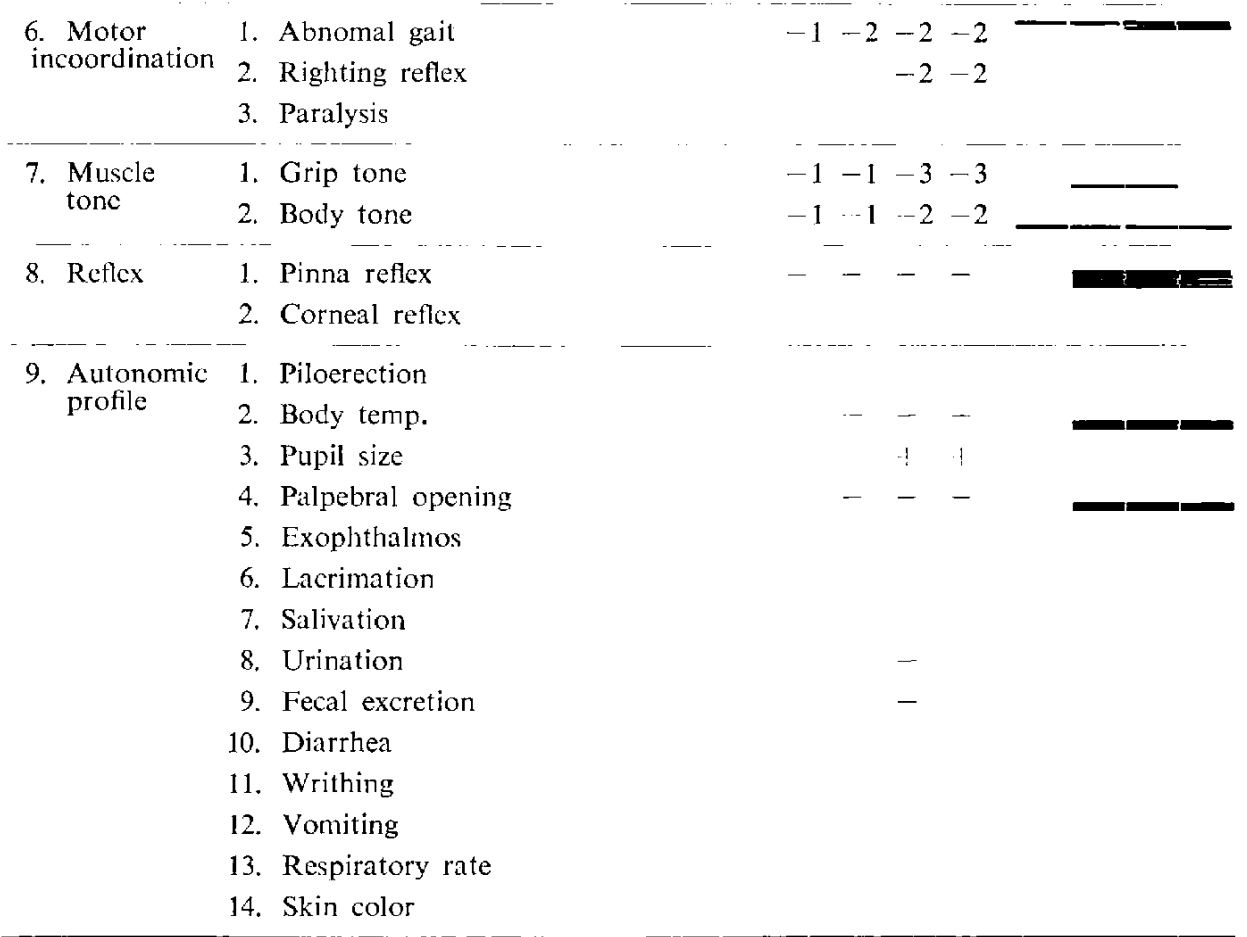

* died in $24 \mathrm{hr}$ after administration

*** died in 10 min after administration

ing effects: a slight decrease in alertness, grooming, spontaneous movement and body temperature. A slight relaxation of skeletal muscle, abnormal gait and ptosis were also observed. These effects apoeared to be dose-dependent. The peak of the effects lasted from 30 to $180 \mathrm{~min}$ after administration, after which the mice showed renewed vitality.

2) G. No. 4

Table 2 shows the pattern of changes in general behavior induced by G. No. 4 in mice. From the number of survivors in each group, an approx. intraperitoneal $L_{311}$ of $G$. No. 4 in mice was presumed to be more than $500 \mathrm{mg} / \mathrm{kg}$ and less than $1000 \mathrm{mg} / \mathrm{kg}$.

$1000 \mathrm{mg} / \mathrm{kg}$ of G. No. 4 produced a decrease of alertness, grooming, motor activity and body temperature, and an increase of passivity immediately after administration. Writhing, abnormal gait, ptosis, relaxation of skeletal muscle, disappearance of righting reflex and pinna reflex were also observed at the same time.

These behavioral changes, except for writhing, lasted for several hours with the mice dying $24 \mathrm{hr}$ after administration. Writhing disappeared $1 \mathrm{hr}$ after administration. In doses of $10-500 \mathrm{mg} / \mathrm{kg}$ given intraperitoneally to mice, the drug produced biphasic effects, that is, the effects didn't appear to be dose-dependent.

In doses of $100-500 \mathrm{mg} / \mathrm{kg}$ : a slight decrease of alertness, grooming, spontaneous movemen1, body temperature, touch response, production of abnormal gait, writhing and ptosis were seen. The duration of these effects was about $2 \mathrm{hr}$, after which the mice 
TABLE 2. Effect of G. No. 4 on neuropharmacological observations in mice. The score card for G. No. 4 shows results obtained in ncuropharmacological screening procedure of Takagi et al. (29).

Central and autonomic nervous system acitivity and acute toxicity screen

$$
\text { G. No. } 4
$$

Strain : ddy, Sex : $\{$, Weight : 18-20 g.

Vehicle : Saline, $\mathrm{pH}: 4 \sim 5$, Route : i.p.,

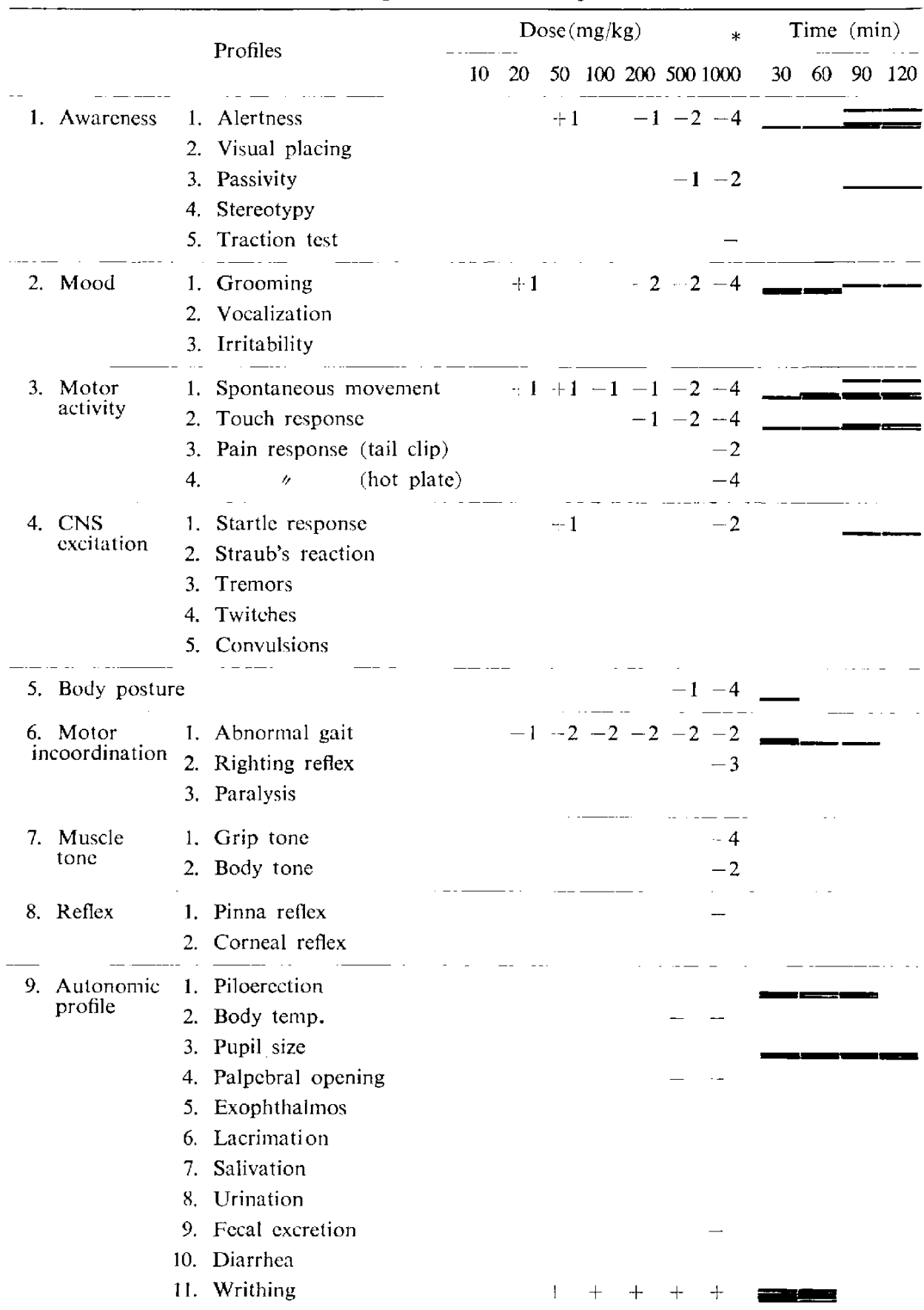


12. Vomiting

13. Respiratory ratc

14. Skin color

* died $24 \mathrm{hr}$ after administration

TABLE 3. Effect of G. No. 5 on neuropharmacological observations in mice. The score card for G. No. 5 shows results obtained in neuropharmacological screening procedure of Takagi ct al. (29).

Cental and autonomic nervous system activity and acute toxicity screen

$$
\text { G. No. } 5
$$

Strain : ddy, Sex : $\hat{o}$, Weight : 18-20g

Vehicle: saline, $\mathrm{pH}: 35 \sim 40$, Route : i.p.,

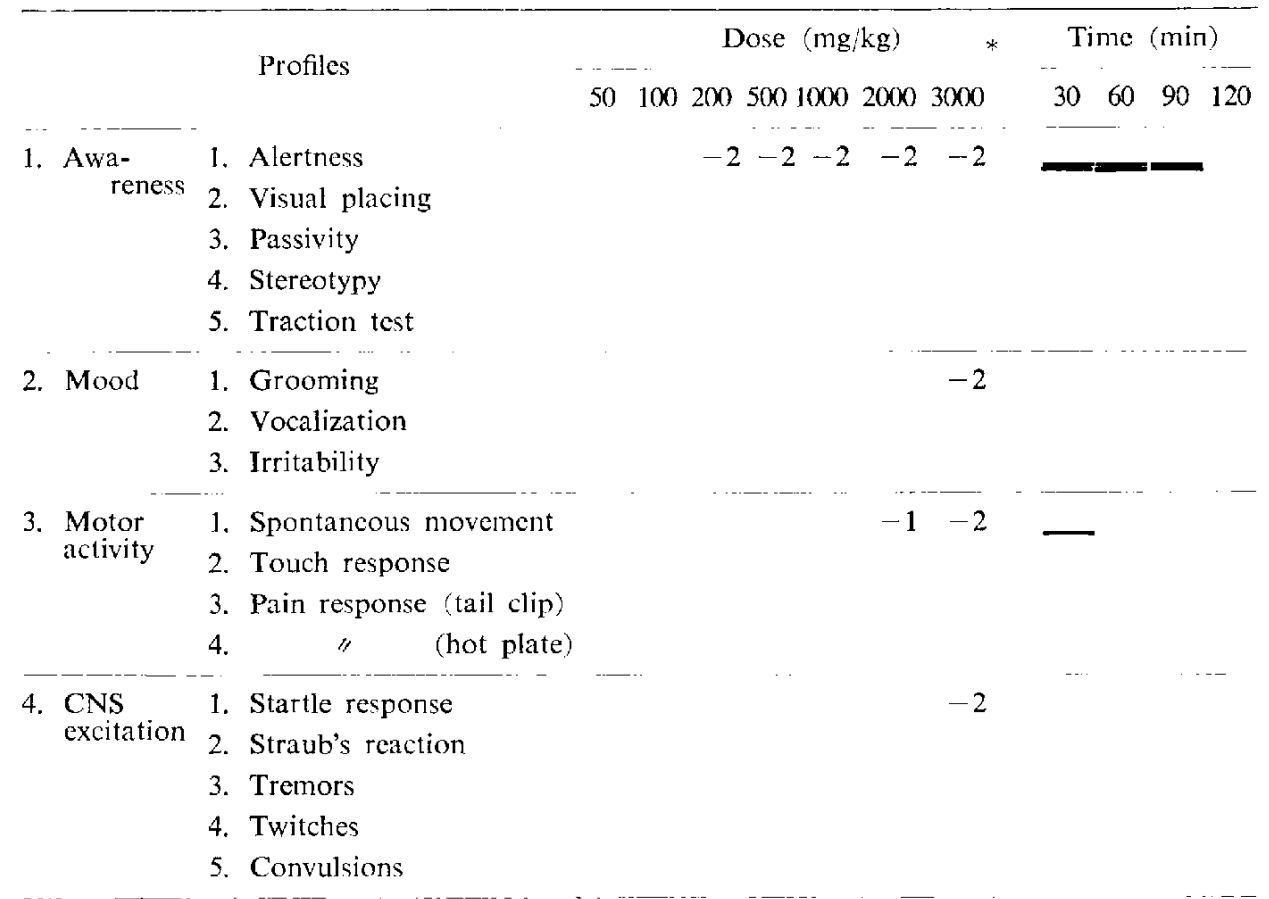

5. Body posture

6. Motor incoordination

1. Abnormal gait

2. Righting reflex

3. Paralysis

7. Muscle tone

1. Grip tone

2. Body tone

8. Reflex

1. Pinna reflex

2. Corneal reflex

9. Autonomic profile
1. Piloerection

2. Body temp.

3. Pupil size

4. Palpebral opening

5. Exophthalmos 
6. Lacrimation

7. Salivation

8. Urination

9. Fecal excretion

10. Diarrhea

11. Writhing

12. Vomiting

13. Respiratory rate

14. Skin color

* died $1 \mathrm{hr}$ after administration

returned to normal states.

In small doses of $10-50 \mathrm{mg} / \mathrm{kg}$ : increases of alertness, grooming, spontancous movcment and startle response were seen. Writhing and abnormal gait were also observed in of these doses. Writhing and abnormal gait appeared immediately after administration administration and lasted for $30 \mathrm{~min}$.

Increases of alertness, grooming, spontaneous movement and startle response were recognized $90 \mathrm{~min}$ after administration and lasted for $1 \mathrm{hr}$. In these doses, there were no depressed states in mice for the first $1 \mathrm{hr}$ after administration.

3) G. No. 5

Table 3 shows the pattern of changes in general behavior induced by G. No. 5 in mice. From the number of survivors in each group, an intraperitoneal $L_{50}$ of $G$. No. 5 in mice was more than $2000 \mathrm{mg} / \mathrm{kg}$ and less than $3000 \mathrm{mg} / \mathrm{kg}$. A lethal dose of G. No. 5 produced the following effects: decreases of alertness, grooming, spontaneous movement and body temperature, in addition, writhing, abnormal gait and relaxation of skeletal muscle were also observed.

In doses of $50-200 \mathrm{mg} / \mathrm{kg}$, the drug produced writhing and abnormal gait immediately after administration, the effects lasting for $30 \mathrm{~min}$. Decreases of alertness and grip tone could be recognized. The mice treated with the drug returned to normal states after a few hr. These effects appeared to be dose-dependent.

2. Tests on the respiratory and the cardiovascular system in rats

\section{l) GNS}

The arterial blood pressure of the rat showed a prolonged hypotension to intravenous injection of GNS $(10-50 \mathrm{mg} / \mathrm{kg})$ as shown in Fig. 2. Following intravenous injection of GNS at a dose of $5 \mathrm{mg} / \mathrm{kg}$, effects on blood pressure, heart rate and respiration were nil. In 5 rats given $10 \mathrm{mg} / \mathrm{kg}, 20 \mathrm{mg} / \mathrm{kg}$ and $40 \mathrm{mg} / \mathrm{kg}$, the mean arterial hypotensive responses increased in 9,21 and 30\% of normal blood pressure respectively. The duration of this hypotension was about 5,9 and 20 min respectively. No effects on respiration and heart rate were seen after these doses, though a slight increase of heart rate was observed in two rats. Tachyphylaxis was not be detected with an injection of GNS.

Effects of acetylcholine $(2 / \mathrm{gg} / \mathrm{kg})$, epinephrine $(5 / \mathrm{g} / \mathrm{kg})$, histamine $(5 / \mathrm{gg} / \mathrm{kg})$, bilateral vagotomy and carotid occlusion on cardiovascular response to GNS were observed. 
Hypotensive doses of GNS did not significantly alter the characteristic blood pressure response of these stimulants.

Intravenous administration of atropine $(2 \mathrm{mg} / \mathrm{kg})$, diphenhydramine $(3 \mathrm{mg} / \mathrm{kg})$ and propranolol $(250 \mu \mathrm{g} / \mathrm{kg}$ ) did not eliminate the hypotensive response to GNS in 5 rats.

\section{2) G. No. 4}

The arterial blood pressure of the rat showed a transient hypotension to intravenous injection of G. No. 4. Decrease in heart rate and the excitatory effect on respiration could be detected in association with the hypotensive phase of the blood pressure to G. No. 4 .

These effects of G. No, 4 on blood pressure, heart rate and respiration could be produced in a dose of $1 \mathrm{mg} / \mathrm{kg}$. In 10

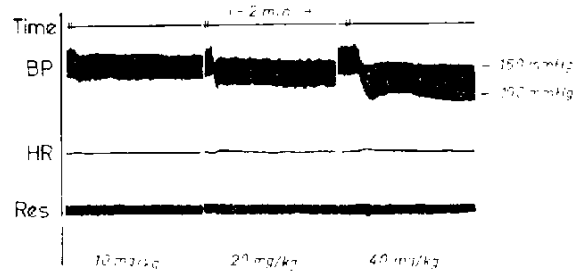

FiG. 2. Effect of GNS on the rat respiratory and cardiovascular system. rats given $10 \mathrm{mg} / \mathrm{kg}$, G. No. 4 lowered the mean arterial blood pressure by about $47 \%$ of normal blood pressure. Duration of this transient hypotension was about $30 \mathrm{sec}$. A decrease of heart rate and excitatory effects on respiration were produced in a dose of 10 $\mathrm{mg} / \mathrm{kg}$. This dose of G. No. 4 did not alter the characteristic response of acetylcholine, histamine, epinephrine on respiration and blood pressure.

The effects of atropine $(2 \mathrm{mg} / \mathrm{kg}$ ) $)$ diphenhydramine $(3 \mathrm{mg} / \mathrm{kg})$ and phentolamine $(0.5$ $\mathrm{mg} / \mathrm{kg}$ ) on respiratory and cardiovascular responses to G. No. 4 were tested as shown in Fig. 3. Propranolol $(250 \mu \mathrm{g} / \mathrm{kg})$ did not eliminate the hypotensive response to G. No. 4 . It was found that with a pre-administration of atropine or diphenhydramine, the hypotensive response of G. No, 4 reversed to transient hypertensive response (Fig. 3). In 5 rats given that $2 \mathrm{mg} / \mathrm{kg}$ of atropine, G. No. 4 elevated mean arterial blood pressure by about $7 \%$ that of normal blood pressurc. Duration of this transient hypertension was about 120

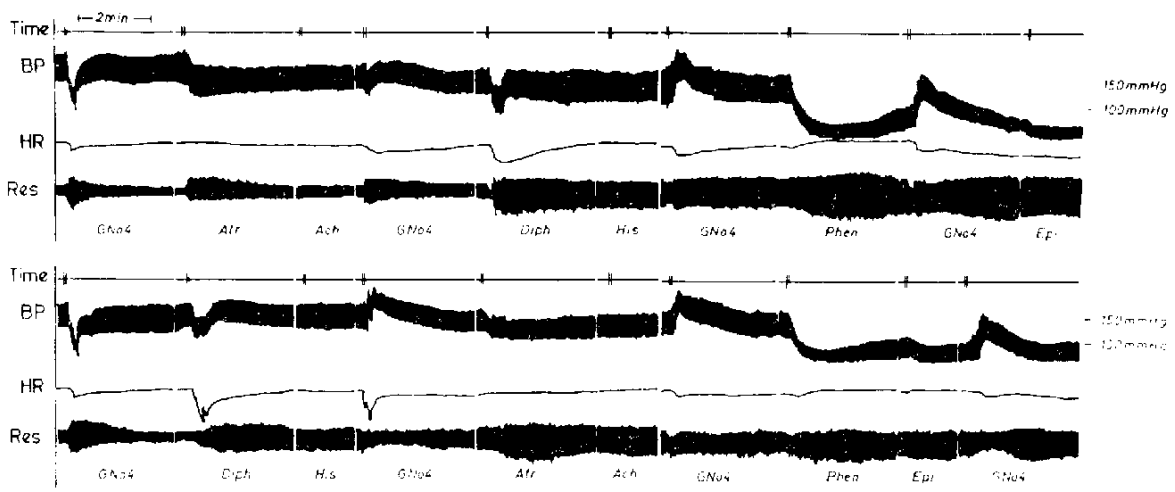

FiG. 3. Effect of G. No. 4 on the rat respiratory and cardiovascular system. ACh (Acetylcholine) : $2 \% \mathrm{~g} / \mathrm{kg}$, Atr (Atropine) $: 2 \mathrm{mg} / \mathrm{kg}$ His (Histamine) : $5 \mu \mathrm{g} / \mathrm{kg}$, Diph (Diphenhydramine $: 3 \mathrm{mg} / \mathrm{kg}$ Epi (Epinephrine) : $5 \mu \mathrm{g} / \mathrm{kg}$, Phen (Phentolamine) $: 0.5 \mathrm{mg} / \mathrm{kg}$ G. No. $4 \quad: 10 \mathrm{mg} / \mathrm{kg}$ 
sec. Decrease of heart rate of G. No. 4 was slightly eliminated, and respiratory stimulation of $\mathrm{G}$. No. 4 was not altered.

In 5 rats given $3 \mathrm{mg} / \mathrm{kg}$ of diphenhydramine, G. No. 4 elevated the mean arterial blood pressure by about $25 \%$. Duration of this transient hypertension was about $150 \mathrm{scc}$. A decrease of heart rate was intensified and respiratory stimulation of G. No. 4 disappeared and respiration was depressed transiently.

In 10 rats simultaneously given $2 \mathrm{mg} / \mathrm{kg}$ of atropine and $3 \mathrm{mg} / \mathrm{kg}$ of diphenhydramine, G. No. 4 elevated the mean arterial blood pressure by about $52 \%$. Duration of this hypertension was about $130 \mathrm{sec}$. Decrease in heart rate was the same as that in the case of atropine, and respiration was transiently slightly depressed.

The hypertensive response of G. No. 4 after the simultaneous administration of atropine and diphenhydramine, was not eliminated by $500 \mathrm{\mu g} / \mathrm{kg}$ of phentolamine.

3) G. No. 5

The arterial blood pressure of rats showed a transient hypotension to intravenous injection of G. No. 5. A slight decrease of heart rate could also be detected, but no effect was seen on respiration (Fig. 4).

Effects of G. No. 5 as a transient hypotension and a slight decrease of heart rate could be observed in a dose of $1 \mathrm{mg} / \mathrm{kg}$.

In 10 rats given $5 \mathrm{mg} / \mathrm{kg}$. G. No. 5 lowered the average of mean arterial blood pressure by about $37 \%$. Duration of this transient hypotension was about $50 \mathrm{sec}$. G. No. 5 ( 5 $\mathrm{mg} / \mathrm{kg}$ ) did not alter the characteristic response on respiration and blood pressure of acetylcholine, histamine and epinephrine. The effects of atropine, diphenhydramine and phentolamine on respiratory and cardiovascular response to G. No. 5 were tested as shown in Fig. 4. Propranolol did not eliminate the hypotensive response to G. No. 5. As in the case of G. No. 4, with the pre-administration of atropine or diphenhydramine, hypotensive

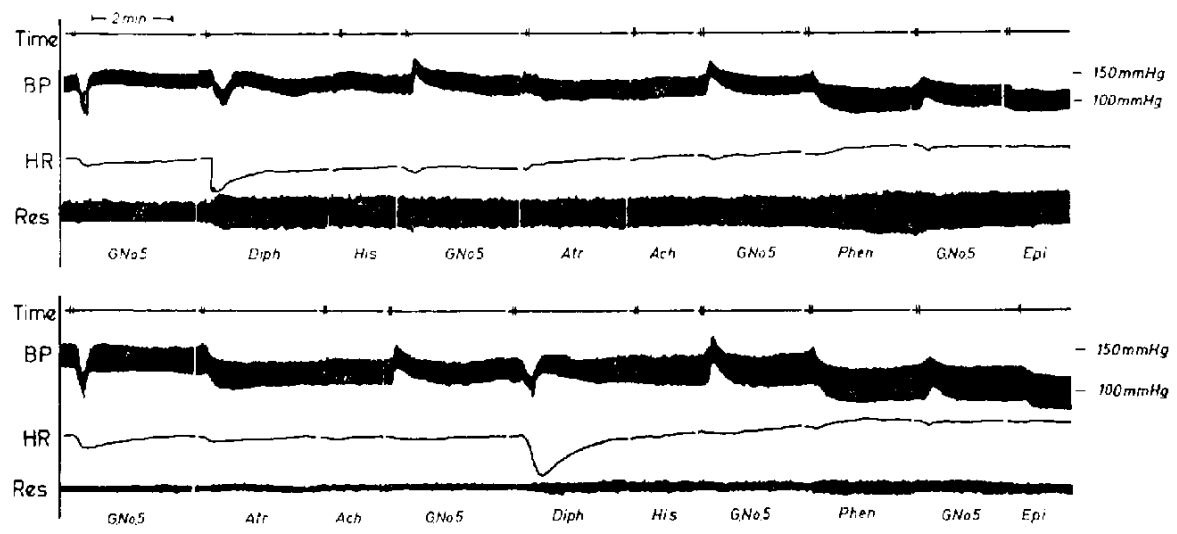

FIG. 4. Effect of G. No. 5 on the rat respiratory and cardiovascular system. ACh (Acctylcholine) : 2 $/ \mathrm{g} / \mathrm{kg}$, Atr (Atropine) $: 2 \mathrm{mg} / \mathrm{kg}$ His (Histamine) : $5 \mathrm{~kg} / \mathrm{kg}$, Diph (Diphenhydramine) $: 3 \mathrm{mg} / \mathrm{kg}$ Epi (Epinephrine) : $5 \mu \mathrm{g} / \mathrm{kg}$, Phen (Phentolamine) $: 0.5 \mathrm{mg} / \mathrm{kg}$ G. No:5 :5 mg/kg 
response of G. No. 5 changed to the transient hypertensive response (Fig. 4).

In 5 rats given atropine, G. No. 5 elevated the average of mean arterial blood pressure by about $42 \%$. Duration was about $90 \mathrm{sec}$. Decrease of heart rate was eliminated, and no effects were seen on respiration.

In 5 rats given diphenhydramine, G. No. 5 elevated mean arterial blood pressure by approx. $29 \%$ Duration was about $40 \mathrm{sec}$. A decrease of heart rate was slightly eliminated and no effects were scen on respiration.

In 10 rats given both atropine and diphenhydramine, G. No. 5 elevated mean arterial blood pressure by approx. $48 \%$. Duration was about 55 sec. $\Lambda$ decrease of heart rate was slightly eliminated and no effects were seen on respiration.

Hypertensive response of G. No. 5 after the administration of both atropine and diphenhydramine, was not eliminated by phentolamine.

3. Tests on the guinca pig isolated ileum

1) GNS

GNS did not induce contraction of the isolated ileum of guinea pig, and effected an inhibition of the log concentration-response curves for acetylcholine (Fig. 5a). The same

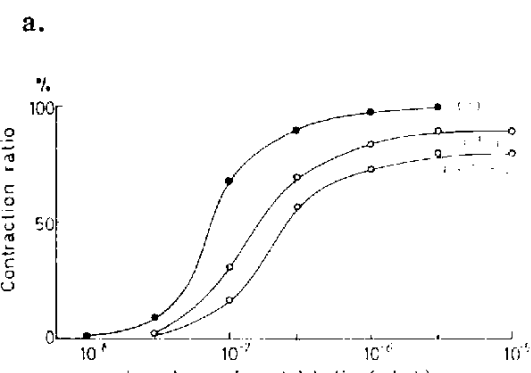

$\log$ dose of acelylcholine $(g / \mathrm{ml})$

c.

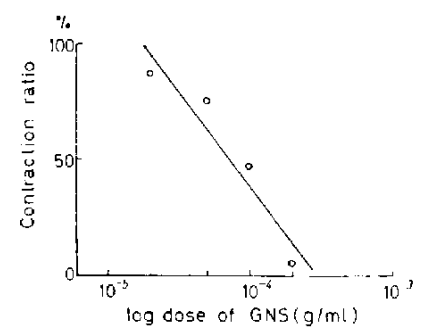

b.

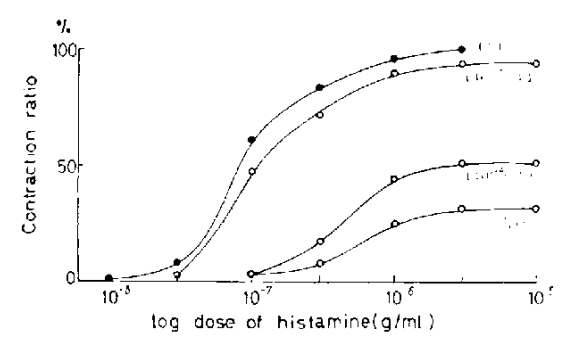

d.

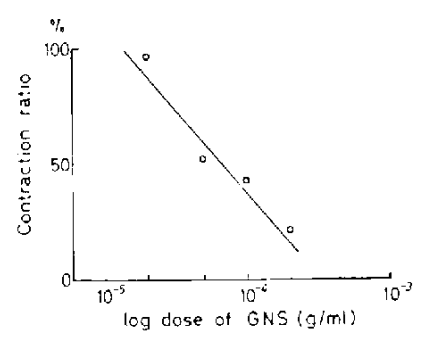

FIG. 5. Effect of GNS on guinea pig isolated ileum.

a. Cumulative dose-response curves for acetylcholine and GNS on the guinea pig isolated ileum.

b. Cumulative dose-response curves for histamine and GNS on guinea pig isolated ileum.

c. Effect of nicotine $\left(3 \times 10^{-1} \mathrm{~g} / \mathrm{ml}\right)$ on guinea pig isolated ileum in presence of GNS.

d. Effect of scrotonin $\left(3 \times 10^{-6} \mathrm{~g} / \mathrm{ml}\right)$ on guinea pig isolated ileum in presence of GNS. 
was found for histamine (Fig. 5b).

Contraction obtained with nicotine and 5-HT in combination with the various doses of GNS are presented in Figs. $5 \mathrm{c}$ and $5 \mathrm{~d}$.

Concentrations of the spasmogens were: nicotine $3 \times 10^{-6} \mathrm{~g} / \mathrm{ml}$, scrotonin $3 \times 10^{-6} \mathrm{~g} / \mathrm{ml}$. These cause approx. $80 \%$ of the maximal contraction of the guinea pig ileum.

GNS antagonized the contraction of ileum induced by nicotine and serotonin.

2) G. No. 4

G. No. 4 did not induce contraction of the isolated ileum of guinea pig, and effected a potentiation of histamine contraction (Fig. 6b). Concentration-response curves for acetylcholine, Fig. $6 \mathrm{a}, 2 \times 10^{-5} \mathrm{~g} / \mathrm{ml}$ of G. No. 4 potentiates the response significantly, but $1 \times 10^{-4}$ $\mathrm{g} / \mathrm{ml}$ of $\mathrm{G}$. No. 4 antagonized in the relatively high concentration of acetylcholine.

G. No. 4 antagonized the contractions induced by nicotine (Fig. 6c), but did not effect these induced by serotonin (Fig. 6d).

3) G. No. 5

G. No. 5 did not induce contraction of the isolated ileum of guinea pig. G. No. 5

a.

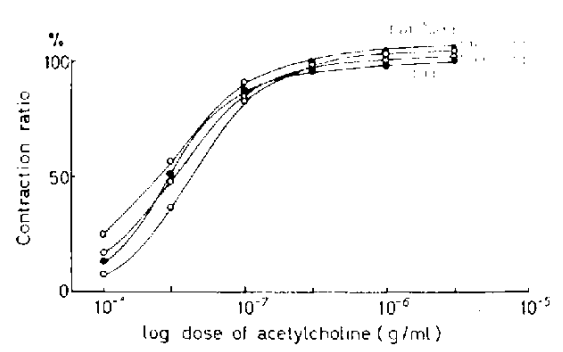

c.

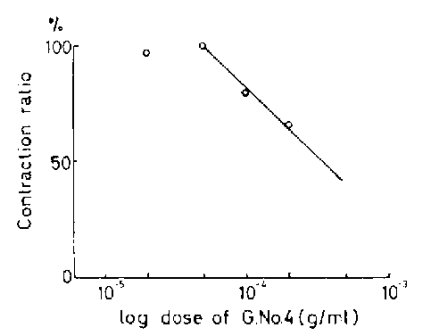

b.

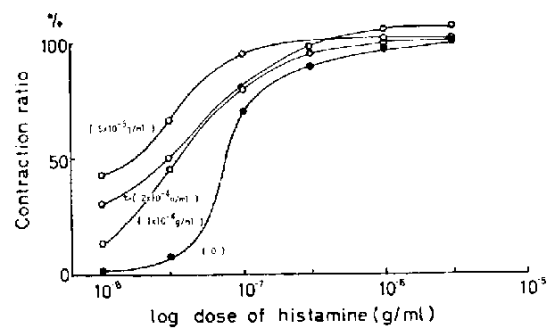

d.

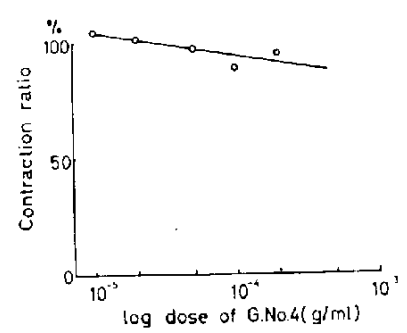

FIG. 6. Effect of G. No. 4 on guinea pig isolated ileum.

a. Cumulative dose-response curves for acetylcholine and G. No. 4. on guinea pig isolated ileum.

b. Cumulative dose-response curves for histamine and G. No. 4 on guinea pig isolated ileum.

c. Effect of nicotine $\left(1 \times 10^{-5} \mathrm{~g} / \mathrm{ml}\right)$ on guinea pig isolated ileum in presence of $\mathrm{G}$. No. 4.

d. Effect of serotonin $\left(3 \times 10^{-5} \mathrm{~g} / \mathrm{ml}\right)$ on guinea pig isolated ileum in presence of $\mathrm{G}$. No. 4. 
a.

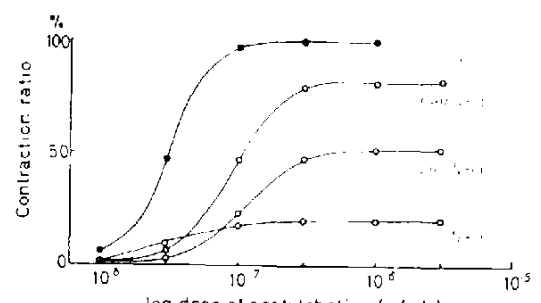

log dose ol acelyicholine $(g / m)$

c.

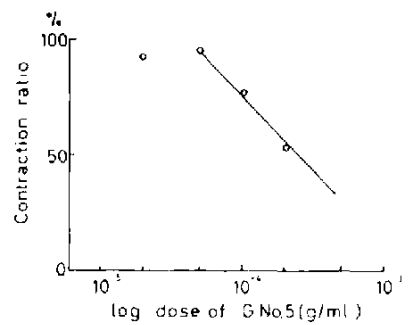

b.

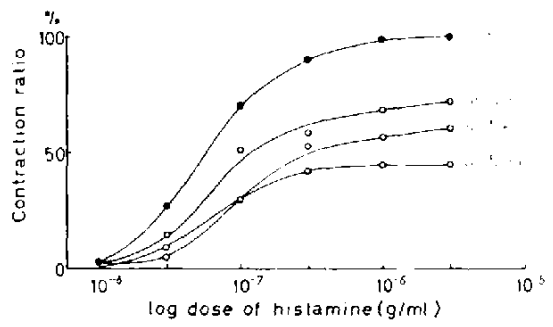

d.

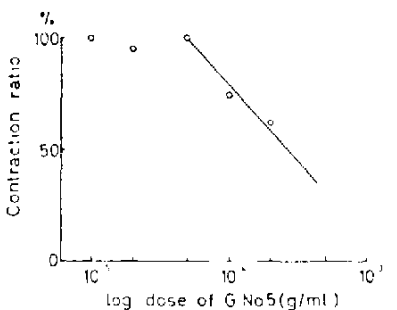

Fic. 7. Effect of G. No. 5 on guinca pig isolated ileum.

a. Cumulative close-response curves for acetylcholine and G. No. 5 on guinea pig isolated ileum.

b. Cumulative dose-response curves for histamine and G. No. 5 on guinea pig isolated ileum.

c. Effect of nicotine $\left(1 \times 10^{-3} \mathrm{~g} / \mathrm{ml}\right)$ on guinea pig isolated ileum in presence of $\mathrm{G}$. No. 5.

d. Elfect of scrotonin $(3 \times 106 \mathrm{~g} / \mathrm{ml})$ on guinea pig isolated ileum in presence of G. No. 5 .

inhibited the response for acetylcholine and histamine, Figs. $7 \mathrm{a}$ and $7 \mathrm{~b}$, and also antagonized the contraction induced by nicotine and scrotonin (tigs $7 \mathrm{c}$ and $7 \mathrm{~d}$ ).

\section{DISCUSSION}

Estimation of the pharmacological properties of GNS, G. No, 4 and G. No. 5, were attempted from the results of blind screening.

1) Netropharmacological observation in mice

Data of GNS on neuropharmacological observations in mice, were compared with the large mass of data accumulated in our labaratory. A drug which was similar to GNS in its neuropharmacological spectrum could not be found. Situations were same for G. No. 4 and G. No. 5.

An attempt was made to interpret possible pharmacological properties of GNS, G. No. 4 and G. No. 5. In GNS, CNS-depressant action was found. GNS lowered body temperature, reduced spontancous movennent, decreased alertness and relaxed muscle tone. The traction test (31), dose ratio of corneal reflex and pinna reffex (32), dose ratio of the reduction of spontaneous movement and the decrease of awareness, lowering of body tem- 
perature and ptosis strongly indicate tranquillization.

Central myorelaxant and analgesic actions were also presumed. The possibility of neuromuscular blocking action was presumed from body posture, relaxation of muscle tone, and also that of ganglion blocking action from the reduction of spontaneous movement, lowering of body temperature and enlargement of pupils.

In a small dose of G. No. $4(5-10 \mathrm{mg} / \mathrm{kg})$, CNS-stimulant action can be presumed, as it slightly increased alertness, spontaneous movement and startle response of mice to loud noise. CNS-stimulant action appeared approx, from $60 \mathrm{~min}$ to $120 \mathrm{~min}$ after administration. In relatively large doses of G. No. 4, CNS-depressant action was predominant. G. No. 4 lowered body temperalure, reduced spontaneous movement and touch response, and dccreased alertness. G. No. 4 induced writhing and abnormal gait in almost all doses administered.

In G. No. 5, writhing and abnormal gait were induced in all doses. Nothing could be estimated from the data on neuropharmacological observation except for irritant action. 2) Tests on the respiratory and the cardiovascular system in rats

GNS caused a fall in arterial blood pressure, and no cffects of GNS on heart rate and respiration were observed. GNS did not alter the characteristic response to a series of stimuli, and the hypotensive response to GNS was not eliminated by atropine, diphenhydramine and propranolol. As GNS resulted in the fall of arterial blood pressure it could have ganglion blocking activity.

GNS may not have similar ataractic activity to that of chlorpromazine, as chlorpromazine diminishes responses to a series of stimuli except to that of acetylcholine. GNS may not have ganglion-blocking activity because ganglion-blocking agents diminishes response to vagal stimulation and carotid occlusion while the other responses were only changed slightly.

G. No. 4 caused the blood pressure to fall transiently, diminished the heart rate and accelerated respiration. Though G. No. 4 did not change the response to a series of stimuli, the hypotensive response of G. No. 4 reversed to the transient hypertensive response after the injection of both atropine and diphenhydramine. This hypertension was not eliminated by phentolamine. It may have muscarinic activity like acetylcholine or histaminergic activity, or vasodilative or cardiodepressant activity. G. No. 4 may have vasopressive activity, as hypertensive response after administration of both atropine and diphenhydramine appeared transiently. It also could have analeptic activity.

G. No. 5 caused the blood pressure to fall transiently, diminished the heart rate slightly like G. No. 4, with no effect on respiration. G. No. 5 did not alter the blood pressure response to a series of stimuli, and the hypolensive response of G. No. 5 reversed to the transiently hypertensive response by preadministration of atropine, diphenhydramine or both atropine and diphenhydramine. This hypertension was not climinated by phentolamine.

From these results, G. No. 5 may have muscarinic and histaminergic activitics, vasopressive, vasodilative or cardiodepressant activity as G. No. 4. Judging from these data, there seemed no possibility of analeptic activity. 
3) Tests on the gutinea pig isolated ileum

GNS, G. No. 4 and G. No. 5 did not induce conlraction of the isolated ileum of guinea pig.

All four of the stimulants acetylcholine, histamine, nicotine and serotonin were inhibited by GNS to about the same degree, therefore it could have a direct depressant action like papaverine, or sympathomimetic activity.

G. No. 4 may have histaminergic, muscarinic and anticholinesterase activities, as it potentiates histamine and acetylcholine, however high concentration of G. No. 4 antagonized acetylcholine. As G. No. 4 inhibjted nicotine, it could have ganglion blocking activity, as well as local anaesthetic properties.

As G. No. 5 antagonized all four of the stimulants like GNS, it may have a papaverinelike activity or sympathomimetic activity.

GNS may have activities such as CNS-depression, tranquillization, analgesia, central myorelaxation and papaverine-like activities. The possibility of vasodilative, neuromuscular blocking, ganglion blocking and sympathomimetic activities remains.

G. No. 4 and G. No. 5 contain more than 3 pharmacologically active substances.

G. No. 4 may have activities such as CNS-stimulation, CNS-depression, muscarinic, histaminergic and irritunt. The possibility of sedative, ganglion blocking, anticholinesterase, cardiodepressant, vasodilative, and vasoconstrictive activities remains.

G. No. 5 may have activities such as papaverine-like and irritant. The possibility of sympathomimetic, muscarinic, histaminergic, cardiodepressant, vasodilative and vasoconstrictive activities also remains.

Further experiments are required in order to establish exact pharmacological activities. Experiments on the cardiovascular system are required to determine the hypertensive activities of G. No. 4 and G. No. 5 .

\section{SUMMARY}

1. Pharmacological properties of GNS, G. No. 4 and G. No. 5 obtained from Ginseng roots, were estimated by blind screening consisting of three tests: I) neuropharmacological observation in mice, II) tests on the respiratory and the cardiovascular system in rats, III) tests on the guinea pig isolated ileum.

2. GNS may have CNS-depressive, ataractic, analgesic and central myorelaxant activities from test $I$, presence of ataractic activity may be estimated from tests I and II, and papaverine-like activity may be estimated from test III.

3. G. No. 4 and G. No. 5 contain more than 3 pharmacologically active substances concluded from test II, i.e., muscarinic and histamine-like substances as well as a substance which raises blood pressure after the administration of atropine and diphenhydramine.

4. G. N.o 4 may have CNS-stimulant from tests I and II, CNS-depressant from test I, muscarinic and histamine-like from tests II and III.

5. G. No. 5 may have papaverine-like activity from test III. 
Acknowledgements: We are grateful to Professor S. Shibata, Faculty of Pharmaceutical Sciences, University of Tokyo and Professor O. Tanaka, School of Medicine, Hiroshima University for kindly supplying the Ginseng root extracts. Thanks is also due to Research Laboratory, Takeda Chemical Industry Co. Ltd., Osaka for supplying Ginseng root.

\section{REFERENCES}

1) Garrique, S.: Am. Chcm. Pharm, 90, 231 (1854)

2) Asahina, Y. And Taguchi, B.: J. Pharm. Soc. Japan 26, 549 (1906)

3) Kondo, H. ET al.: J. pharm. Soc. Japan 35, 779 (1915)

4) Kotake, M.: J. chem. Soc. 51, 357 (1930)

5) Horhammer, L., Wagner, H. and Lay, B.: Pharm. Ztg. 106, 1307 (1961)

6) LIN, Y.T.: J. Clin. chem. Soc. 8, 109 (1961)

7) Wagnt.r-JourlgG, Th. And Roth, M.: Pharm. Acta Helvet. 37, 352 (1962)

8) Eliakov, G.B., Striena, L.T., Charlin, A.Y. and Kochetkov, N.K.: Izvest. Acad. Namk, USSR. 1125 (1962)

9) Shibata, S., Fujita, M. and Itokawa, H.: J. pharm. Soc. Japan 82, 1634 (1962)

10) Shibata, S., Fujita, M., Itokawa, H., Tanaka, O. and Ishil, T.: Tetrahedron Letters 10, $419(1962)$

11) Shlibata, S., Fujita, M., Itokawa, H., Tanaka, O. and IshiI, T.: Chem. pharm. Bull. 11, $759(1963)$

12) Sinbata, S., Tanaka, O., Ando, T., Sado, M., Tsushima, S. and Ohsawa, T.: Chem. pharm. Bull. 14, 596 (1966)

13) Tanaka, O., Nagial, M. and Shibata, S.: Chem. pharm. Bull. 14, 1150 (1966)

14) Shibata, S., Ando, T. and Tanaka, O.: Chem. pharm. Buil. 14, 1157 (1966)

15) Tanaka, O., Nagai, M., Ohsawa, T., Tanaka, N. and Shibata, S.: Tetrahedron Letters 5, $391(1967)$

16) Nagat, M., Ando, T., Tanaka, O. and Shibata, S.: Tetrahedron Letters 37, 3579 (1967)

17) Kondo, J.: Folia phurmac. japon. 5, 201 (1927)

18) Esdoru, 1.: Pharmazic 13, 556 (1958)

19) Scrulz. B,: Disch. Apothztg. 98, 127 (1958)

20) Schulz, B.: Disch. Apothztg. 99, 303 (1959)

21) KITAGiAWA, H. AND IWAkI, R.: Folia pharmac. japon. 59, 348 (1963)

22) Petkov, W.: Arch. exp. Path. Pharmak. 236, 298 (1959)

23) Pletkov, W.: Arzneimittel-Forschung 11, 288 (1961)

24) Petkov, W.: Arzheimittel-Forschung 11, 418 (1961)

25) Yoon, S.R.: Korean Med. J. 5, 99 (1960)

26) MYERHOFF, W.K.: Deutsch. Med. J. 10, 368 (1959)

27) HWang, W.T.: Bull. Chonnam. Univ. 5, 425 (1960)

28) Wood, W.B., ROH, B.L. AND WIITE, R.P.: Jap. J. Pharmac. 14, 284 (1964)

29) Takagi, K., Saito, H., Higuch, Y. and Yamaguchi, A.: Pharmacometrics 5, 5 (1971)

30) Irwin, S.: Science 136, 123 (1962)

31) Turner, R.A.: Screcning Method in Pharmacology, p. 89, Academic Press Inc., New York (1965)

32) Janssen, P.A.J.: J. Pharm. Pharmac. 13, 513 (1961) 